\title{
Democratization Through Enlargement: A Comparative Study of Bosnia and Herzegovina and Kosovo
}

\author{
Stiliano Rushaj, Phd Candidate \\ European University of Tirana \\ rushajstiliano@gmail.com
}

\section{Doi:10.5901/mjss.2015.v6n4s1p467}

\section{Abstract}

\begin{abstract}
After more than 20 years of transitory journey for former-communist countries of Western Balkans, democratization still face challenges to implement or/and consolidate. Some of them share post-conflict experience and lack economic and political resources. The main challenge is faced on the enforcement of the rule of law which has a direct influence on the enhancement of the civil liberties within each country. Insofar taking into consideration the EU engagement in the region I will ask how does the Enlargement process, through political conditionality, influence the enhancing of democratization in Bosnia and Herzegovina and Kosovo? I answer the following question through this argument that, although EU strength coercive pressure through Conditionality regarding the enforcement of Rule of Law and enhance of civil liberties, democratization in post-conflict countries of SEE, stagnate. In this paper, first I analyze a background of democratization, from the EU enlargement perspective. Than on the second part I analyze the EU conditionality toward the enforcement of the rule of law and enhance of civil liberties on the two case studies. In the third part, a comparative analysis between the cases will prove the above assumption that this paper argue.
\end{abstract}

Keywords: Democratization, EU Enlargement, conditionality, rule of law, civil liberties

\section{Introduction}

The end of the Cold War, appeared with an impressive future for the spread of democratization among the former communist countries of East Europe. This democratic transition in the Western Balkan countries, occurred with a bloody disintegration of former Yugoslavia and the process of democratization was developed in the same with the state and ornational-building of this new countries. The EU engagement in the region was seen as prospect for the whole region to manage its future more prosperous economical gains and a consolidated democracy. But after 10 years from the beginning of the Enlargement process ${ }^{1}$, democratization of these countries is challenged, due to low institution implementation of the enforcement of the rule of law and in the same vain low civil liberties enhacement. This problematic is clearly seen in two of countries of region: Bosnia and Herzegovina (here and after BiH) and Kosovo. Their process seems stagnated and also EU expectations toward them has fallen.

The aim of this paper is to understand the EU engagement in the process of democratization in this two countries and in this regard I ask: How does the Enlargement process, through political conditionality, influence the enhancing of democratization in Bosnia and Herzegovina and Kosovo?

The comparison of this two countries is taken because, firstly they share a common legacy from the Yugoslavia: former post-conflict entities that started a process of peacebuilding with transformative state-building mostly externallydriven which in one hand meant to establish basic state institutions acceptable for all domestic actors and on the other hand to follow the integration process as the other countries of the region. They both share stateless situation, where for instance BiH face uncertain for the unity (in the state level) and Kosovo which faces a problem of unity (acceptance of the serbs municipalities for the government role of Prishtina institutions) and international recognition. Thus, BiH has a signed Stabilization Association Agreement but still has not entered into force and Kosovo initialled the SAA, being insofar the last in the region. Taking account the similarities that these countries share, I argue that, although EU strength coercive

\footnotetext{
1 The Enlargement process started just after the Thessaloniki summit of 2003, which officially declared that the WB countries has a future as members of EU. The countries meant to have compliance first with the Copenhagen criteria that was the first step of the country being eligible to start negotiation with the union. Except Croatia (2014), all the other countries of WB have had a long way only to be candidate states. In fact Bosnia and Herzegovina and Kosovo still are in the process to gain first the Stabilization Association Agreement, and afterward to be eligible as potenetial candidate.
} 
pressure through Conditionality regarding the enforcement of Rule of Law and enhancement of civil liberties, democratization in post-conflict countries of SEE, stagnate.

This argument will serve as the main vector of the paper. In the first chapter I will analyze the background of democratization, from the EU enlargement perspective. Than on the second part I analyze the EU conditionality toward the enforcement of the rule of law and enhancement of civil liberties, first in the BiH case study and after it Kosovo. In the third part, a comparative analysis between the cases will present an explanation for the main question that this paper seek.

\subsection{Research Methods}

From the state of literature there is an ample availability of studies regarding democratizations in former coumunist countries or post-conflict one. This paper will draw mainly its analysis from the work of Schimmelfennig F., Sedelmeier U. and Tocci N. ${ }^{2}$. Methodologically it will be grounded on qualitative methods and I will use primary data from EU Commission progress reports and the Economist Democracy Index. The Commission reports will give more insights on the countries progress based on the rule of law enforcement and enhance of the civil liberties and the democracy index rating will support the argumentation why the country has different results during the time taken into the analysis. The analysis will be based on language tracking, when it will be evaluated from the language that the European Commission reports used to express the compliance with Conditionality for each country and each year toward the specific fields: rule of law and civil liberties. Thus the use of "progress", "limited progress" and "no progress" will evaluate the assessment of the country performance. This also will help to build the comparison anaylis between the two case studies and support to reformulate, if it will be required form the results, the main assumption that this paper raises to be the vector of its analysis. Insofar the relevance that this paper presents, is that it seek to analyze the influence that conditionality use toward the democratization in the process of EU integration that this countries are current having. This will create new insights for further analysis and put on discussion further variables to measure democratization in through the EU Conditionality influence.

\section{Democratization Through EU Enlargement Perspective}

Generally, democratization is seen as a process with two main components: reforming the institutional set-up, such as shaping the political landscape to fit a democratic system of governance, and changing behavior to respect the new democratic and liberal norms which accompany a democratic regime ${ }^{3}$. The institutional changes are often not very complicated (democratization of the institutions), but the trouble comes when behavior has to change (democratization of the society). In the same way Welzel and Alexander explains that democratization must be seen in difference between democracy in nominal terms and effective democracy. They explain that, "the existence of popular rights" - in this paper taken as civil liberties - "establishes nominal democracy but the rule of law is necessary to translate nominal into effective democracy"4. Through this assessment we can understand that civil rights and the rule of law interact to produce that amount of effective democracy that a country needs to consolidate its democratic institutions and change the behave into a affirmed democratic society, but then how can external promoter produce a further effective toward democracy.

The EU, is often seen as a value-based community, has to some extent succeeded in transmitting some of its values and norms to third countries, but this process is long and complicated ${ }^{5}$. Since the enlargement process of Central Eastern European countries, conditionality started to be shaped as a tool for the accession process of the target state, with the aim of transforming the governing structures, the economy and the civil society of the (potential) candidate countries. In the broader sense this meant to be a strategy in which a reward is either granted or withheld depending on the fulfillment of an attached condition. More specifically, "political conditionality" was structured as a contractual link, by a state or/and international organization, of perceived benefits to another state, to the fulfillment of conditions relating to the protection of human rights and the advancement of democratic principles". 6

Insofar, the EU conditionality is understood as a dichotomy between "carrots and sticks". The "carrots" are given as

\footnotetext{
${ }_{2}^{2}$ For further reading on the use of conditionality in the enlargement process take account the Central Eastern European countries accession. Some of the main authors that deal with this topic are Schimmelfennig and Sedelmeier 2004; Tocci 2007.

${ }^{3}$ Chandler D., (2003) "The European Union and Governance in the Balkans: A Unequal Partnership", p. 6

4 Welze, Ch.l and Alexander, A.C. (2008) "Measuring Effective Democracy", p.12

${ }^{5}$ Schimmelfennig, F. and Sedelmeier, U. (2004), "Governance by conditionality", p.675

${ }^{6}$ Tocci, N. (2007), "The EU and Conflict Resolution", p.10
} 
a reward to good behavior of the state, usually ranging from economic assistance to full membership. On the other hand "sticks" are used to punish a target state for non compliance with the contracted conditions. In this sense negative conditionality involves the infliction of a punishment on a target state for violating a specified obligation?. This can be further explained by the two common theories regarding conditionality: rationalist and constructivist theories. According to Sedelmeier, rationalist theory see EU domestic impact follows a logic of consequences, in that adaptational pressure from the EU changes the opportunity structure for utility-maximizing domestic actors. It empowers certain actors by offering legal and political resources to pursue domestic change ${ }^{8}$. Unlike constructivism see the continuation of the process of socialization, when domestic actors internalize EU norms because they regard them as legitimate. Constructivists, recognize the role of domestic politics in the accession process"9.

In the end we can argue that, the rule of law and civil liberties that states merely enforce and enhance, through the use of certain contractual links with external promoter of democracy, such as the EU, may influence to the effectiveness of the democratic state and behave. The following chapter will assess how EU conditionality has influenced democratization in the post-conflict Bosnia and Herzegovina and then Kosovo.

\section{Case study: Bosnia and Herzegovina}

In 2005, EU officially opened accession negotiation to BiH. Through nine year the country reached to sign SAA but due to non-compliance with the EU conditions, it is still a potential candidate. This section will analyze the conditionality of EU toward enforcement of rule of law and the enhancement of civil liberties in BiH through two periodical framing: 2005-2010 and 2011-2014. and assess how democratization is influenced through political conditionality.

\subsection{EU Conditionality toward the enforcement of the rule of law}

Beginning with the feasibility study ${ }^{10}$, the rule of law (building institutional-mechanisms to handle it and then to enforce), was found to be a concern for the opening of the process of negotiations for accession. Also the democracy index rated the country ability to rule of law scarce ${ }^{11}$. The EU was supporting the start of negotiation if, the political will would establish a single Ombudsman for the three "constituent peoples" and full cooperation with ICTY12. This conditionality was provided useful because the country was almost in compliance with the EU requirements.

In 2008 the EU and BiH agreed upon a new partnership, the Interim Agreement, from which the rule of law was more persistent regarding judicial system and anit-corruption policy ${ }^{13}$. At that time the Commission was concluding that the only area with substantial progress was the judicial system, in which: "an effective and efficient judicial system has been advancing" and "very little progress" was made on improving its tools to fight corruption ${ }^{14}$. But in the other hand the only area making "no progress" was the reform of the constitutional framework. Also in 2009, minor differences were reported. Regarding the constitutional framework, BIH went from "no progress" to "little progress" and in the judicial system it changed from "advancing" to "little" in 200915.

Starting from 2010, the Commission reported limited progress in the overall process ${ }^{16}$. This situation was also

\footnotetext{
7 Ibid, 11

${ }^{8}$ Sedelmeier, U. (2011), "Europeanisation in new member and candidate states", p. 11

9 lbid, 16

${ }^{10}$ Accordind to the Commision Report on BiH in 2005 the Commision states that the country has received a feasibility study in 2003 in which it suggests that the pre-conditions were not yet fully met, listing sixteen priorities to be addressed before negotiations could be opened." European Commission, BiH, Progress 2005 Report, p. 3-5

${ }_{11} \mathrm{BiH}$ was rated in the 87th place out of 167 countries in the Democracy Index(3.29/10.00). The Economist Democracy Index 2007, p.4

${ }^{12} \mathrm{Also}$, from the 2005 report, it states: "From the feasibility study of 2003, the achievements made in State-building were not reversed. Regarding cooperation with the ICTY, the report considered that Bosnia and Herzegovina had only made limited progress"(European Commision, BiH, Progress Report, 2005, p.8). Also EU offered economic incentives to achieve its requirements, providing IPA founding and other financial assistances for the amount around 200 mio euros.(ibid, p.12)

${ }^{13}$ European Commision, BiH, Progress Report 2008, p.4

14 lbid, p.14-15

${ }^{15}$ European Commision, BiH, Progress Report, 2009, p.9-14

16 "Although the ratification has proceed 25 EU members the Interim Agreemet that was putted as a Conditionality for formalization of the SAA by Bosnia and Herzegovina has been uneven. The country is in breach of the IA due to non-compliance with the European Convention on Human Rights" (European Commision, BiH, Progress Report 2010, p.10)
} 
influenced by the breach of the political will in $2008^{17}$, between constituent ethnies, regarding the reforming of the constitution. This implied a further deterioration of the country democratic perception index. In 2010, BiH performance regarding the rule of law was worst than in 2005, when it started the negotiation for accession. This rate changed somehow the attitude of the EU toward $\mathrm{BiH}$ by freezing the entry into force of SAA ${ }^{18}$. I argue that in this point of the process, the need for constitutional reform played a crucial role, for the continuity of the country integration and framed the main conditionality that EU pressured toward BiH.

Despite the performance, at least until the 2010 , the country had sustainable compliance with the EU conditionality. EU supported $\mathrm{BiH}$ through the ongoing financial instrument (IPA) ${ }^{19}$ and the process of visa liberalization which took a prior stage before full liberalization. ${ }^{20}$ Another important thing to mention is that the major part of the financial allocation during 2008-2010 was given to support the enforcement on the rule of law. In the Commission report states that, "the assistance is offered to the areas of constitutional reform, rule of law..."21, although the performance in judiciary was weak ${ }^{22}$. In this stance I argue that although the low compliance with the EU requirements, the "carrots" that were offered, can be seen more as an encouragement than a reward of the progress achieved.

Until 2014, the country compliance with the EU was vague. The Judiciary met "limited progress" and the corruption sets $\mathrm{BiH}$ as a premature or "still at an early stage in the fight against corruption", because "the political will to tackle the issue and to improve institutional capacity remains weak ${ }^{23 "}$.

\subsection{EU Conditionality toward enhancement of civil liberties}

Civil liberties are a prominent feature of a country to achieve a degree in its democracy. BiH had an institutional infrastructure and ratified a number of international conventions on human rights. Despite that, the 2005 report found that still on Republika Srpska, the death penalty was regulated for capital crimes. This was not compatible with EU standards and issued to be included in the country short-term objectives that the Commission was requesting 24 .

Taking into consideration the democracy index, civil liberties were rated with three out of seven, showing that the country was falling to enhance them ${ }^{25}$. Although EU conditionality was more focused on the enforcement of rule of law, civil liberties as an interconnected sphere for democracy started to be a concern after 2007. The Dsizich and Filinc (2007) case showed the need to reform the constitution, by which the country could fully be in compliance with the (ECHR) ${ }^{26}$. The 2008 progress report stated that: "Although the conventions are directly applicable, implementation needs to improve. As regards the promotion and enhance of civil liberties remains unsatisfactory"27. These were signals that the EU was giving a high priority on them and which would influence the new conditions that the Commission was preparing toward the finalization of the SAA process.

Insofar, the 2010 progress report cleared the voice on the civil liberties stating that the country "had made no further progress" 28 . All areas that this report mentioned were almost not fulfilled compare with the years before when some progress had been achieved. Also, the failing effort of US-EU initiative for constitutional reform through Prud Agreement and the ECtHR legally-binding decision that found ethnicity-based ineligibility to stand for election

\footnotetext{
17 In the framework of the Prud Agreement of November 2008, the leaders of the three main political parties committed themselves to initiate the process of constitutional reform and to introduce measures to harmonise the Constitution of Bosnia and Herzegovina with the European Convention on Human Rights (ECHR).(there was a will to fulfill EU conditions but, political representatives have dfferent view for the country). (European Commision, BiH, Progress Report 2010).

18 The Commission statement on the SAA progress of BiH (European Commision, BiH, Progress Report 2010); The Democracy Index rated $\mathrm{BiH} 9$ places lower than 2007 (Economist Democracy Index 2010, p.5)

19 The IPA assistance in 2008 was 128.9million euro; 2009 was 98.3 million euro; and in 2010 was 74.8million euro. Data cited from European Commission, BiH, progress report for 2008, 2009 and 2010.

20 First the country was given visa facilitation (European Commission, BiH, progress report 2008)

21 European Commision, BiH, Progress Report, 2009, p.12

22 According to the Commission Report of the 2010, "BiH progress in the area of judicial reform has been limited on the whole". (European Commision, BiH, Progress Report, 2010, p.8)

${ }^{23}$ European Commision, BiH, Progress Report, 2014, p.9

24 European Commision, BiH, Progress Report, 2005, p.20

25 The Economist Democracy Index 2007, p.4

26 The case became a serious concern for civil liberties, after the denying of a roma and Hebrew citizen to run for president candidacy from the Election Committee. Immediately the EU saw it as a violation of the Protocol 12 of the ECHR and the case was sent into trial in the European Court of Human Rights.

${ }^{27}$ European Commision, BiH, Progress Report, 2008, p. 23

${ }^{28}$ European Commision, BiH, Progress Report, 2010, p.12
} 
incompatible with the general principles of the ECtHR, which BiH was part of it. Without resolving this incompatibility the process would be blocked. What has changed for the Commission report of 2014 is the public awareness regarding the social-economic situation in the country. This new approach that the Commission mention to use in this regard, express a direct effort toward them by launching three initiatives to shift the focus toward reforms and issues that has direct concern to citizens." 29 This new assessment will have further implication in the following years on how EU will track new strategies to support its conditionality toward other influential actors of the society.

\section{Case study: Kosovo}

In 2013, the EU opened officially the accession negotiation for Kosovo. Currentlly Kosovo has initialled the SAA and through the 2015 is expecting to go forward the process. In this section I will analyze the EU conditionality based in two periodical framing: 2008-2012 and 2013-2014.

\subsection{EU Conditionality toward the enforcement of the rule of law}

Kosovo is the newest country in the region that is aiming to sign the SAA. Since its declaration of independence in 2008, EU was more involved (EULEX mission). The 2008 progress report was not the first one that the Commission had prepared for Kosovo, but it was meant as a pre-feasibility study to assess the overall institutional infrastructure that the new country had created. In the 2009, Kosovo was tracking a favorable way toward its goals but as the report stated: "has to make further progress in establishing and consolidating the rule of law and needs to improve the functioning and independence of its judiciary" ${ }^{\prime 3}$. EU conditionality was based on the requests of institution-building (Constitutional Court) and public agencies in monitoring the fight against corruption and other forms of organized crime and delivering as a reward the starting of the visa liberalization dialogue.

The 2010 and 2011 progress reports, showed in overall that this progress had been achieved. Regarding the judiciary sector, the Commission expressed that: "Kosovo has made progress in this area"31 and on the anti-corruption policy the country "has been achieved progress" ${ }^{32}$ Also these achievements were reliable due to Kosovo ranking in democracy index, assessed positively from the previous years 33 .

In this instance the country was ready to met the feasibility study progress which evaluated Kosovo for starting official accession negotiation. The Commission reported that "over the past three years, the functioning of democratic institutions and the respect for the rule of law have been consolidated. The necessary institutions have been established." ${ }^{4} 4$ This statement was seen as an effort for the country to have an official opening and also assesses the overall achievement done through the EU conditionality since 2008.

With this condition and requirements the EU did not forgot the reward and encouragement. In the case of Kosovo there have been only on financial assistance. IPA funding amounted nearly $400 \mathrm{mln}$ euros. ${ }^{35}$ The visa liberalization was meant as mid to long term perspective for the country although visa facilitation have been achieved. This may be explained as different approaching respect previous in haste rewarding in the case that I have analyzed in $\mathrm{BiH}$. Nowaday Kosovo is still pending for the visa liberalization.

The two last progress reports, 2013 and 2014 were issued during the country process for SAA. Overall the enforcement on the rule of law has been marked by positive acknowledgment by the union but with a vivid concern" 36 . This logic that EU is deploying in Kosovo has some familiarities with the UN led approach "Standards before status"37, meaning more efforts from country institutions for democratization than the EU will reward. With this assumption I will analyze the enhancement of civil liberties in Kosovo through the EU conditionality.

\footnotetext{
${ }^{29}$ European Commision, BiH, Progress Report, 2014, p.17

30 European Commision, Kosvo, Communication, 2009, p.3

31 European Commision, Kosovo, Progress Report, 2010, p.10

32 European Commision, Kosovo, Progress Report, 2011, p.13

${ }^{33}$ Economist Democracy Index 2010, p.5

${ }^{34}$ European Commision, Kosovo, Communication, 2012, p.5

${ }^{35}$ Between 2008 to 2012, IPA founding provided an overall amount of 400million euro. Data gathered from European Commision, Kosovo, Progress Report, 2008, 2009, 2010, 2011 and 2012.

${ }^{36}$ European Commision, Kosovo, Progress Report, 2013, p.8

37 "Standards for Kosovo" A Security Council Report, 2003
} 


\subsection{EU Conditionality toward enhance of civil liberties}

Regarding civil liberties the 2008 progress report found the overall situation in Kosovo's, institutions, laws and government approach sustainable. Despite, the 2009 report found that Kosovo had a need to improve the protection of Serb and other minorities and enhance dialogue and reconciliation between the communities. In overall the social cohesion was in need to be strengthened"38. These requests were also implied in the enhanced EU approach for Prishtina-Belgrade dialogue in 2012.

Insofar the dispute international status that the country has, can not enforce the human rights instruments because it is not subject to the frameworks to any international bodies for regular reporting and cooperation on human rights, that is why the report of 2010 recommended to have more dialogue with the EU representative institutions ${ }^{39}$. In 2011 and 2012 progress reports, the Commission was "inviting Kosovo to intensify reforms in the area of civil liberties and protection of human rights and focus on implementation" 40 . For the Commission: "The pace of progress depends on Kosovo." ${ }^{1}$. I argue that this language used by EU is an effort for the achievement of Prishtina-Belgrade dialogue. This perception will be explored in 2013 as the political conditionality that EU imposed to both countries to achieve: starting negotiations for SAA (Kosovo) and entry in force of SAA (Serbia).

In 2013 the change of the language is seen clearly: "Following the end of supervised independence in September 2012, Kosovo's legal framework continues to guarantee minority representation". ${ }^{42}$ In the same vain it continues in 2014 report: "Overall, Kosovo has made some progress on the protection of human rights and enhance of civil liberties". ${ }^{43}$ This is furthered maintained when it express: "Kosovo's progress towards its European future has been possible due to the progress made by Kosovo in the reforms and its continued commitment to the normalization of its relations with Serbia, which has seen significant progress" 44 . Although the logic would be in the same way as regarding the enforcement the rule of law, I argue that this year, Kosovo has a right to have expectation for possible "carrots" so much needed for the country and society in overall.

\section{Comparative Study}

After analysing each case studies over the EU conditionality toward the enforcement of the rule of law and enhancement of the civil liberties, as preconditions of democratization, I argue that in the case of $\mathrm{BiH}$ the EU started to use conditionality since the feasibility study in 2003 . The country achieved some progress until 2008 when the Commission reported mainly "some progress" on the rule of law and civil liberties. This was also assessed in the democracy index rating were indicators relating to the fields on rule of law and civil liberties marked a positive shift toward the previous years. EU rewarding were mostly on the financial assistant (IPA). Differently, the case of Kosovo showed that EU conditionality started to be used since the declaration of its independence, pre-feasibility study (2009). EU was rewarding the country with IPA funding also, if it would comply with the Commission requests. The achievements started to be relevant mostly in the rule of law, when the Commission stated mostly "some progress" till 2012, but on the civil liberties the assessment was critical because the EU was pushing the country to achieve dialogue with Belgrade.

By $2010 \mathrm{BiH}$ went to a deadlock because of major non-compliance with EU requirements and the entry into force of SAA was blocked. Although EU differentiated its rewarding by applying encouragement for the process, issuing the visa liberalization program in December of the same year. This approach did not bring the expected results in the years that followed. In the case of Kosovo although the country achieved some progress with EU requirements, the union was expecting more to be done by the political will and then to reward the country with the opening of the accession negotiation process. In fact this was achieved only in 2013 and differently from BiH. Insofar EU changed its attitudes toward $\mathrm{BiH}$ non-compliance by blocking the IPA funds and warned for freezing also the visa liberalization ${ }^{45}$. The progress reported by the Commission went from "limited progress to very little" between 2010 and 2014. In the case of Kosovo the Commission reported "some to limited progress" and the EU is expecting the achievements of certain progress to offer the amount of incentives as rewarding.

\footnotetext{
${ }^{38}$ European Commision, Kosovo, Communication, 2009, p.9

${ }^{39}$ European Commision, Kosovo, Progress Report, 2010, p.19

${ }^{40}$ European Commision, Kosovo, Progress Report, 2011, p.16

${ }^{41}$ European Commision, Kosovo, Communication, 2012, p.7

${ }^{42}$ European Commision, Kosovo, Progress Report, 2013, p.7

${ }^{43}$ European Commision, Kosovo, Progress Report, 2014, p.12

${ }^{44}$ Ibid, p. 15

${ }^{45}$ European Commision, BiH, Progress Report, 2014, p.19
} 
I argue that in the case of $\mathrm{BiH}$ the conditionality used influence on some degree to enforce the rule of law and enhance the civil liberties in the first phase (2005-2008) and there was a balance between requests and incentives. But between 2008-2010, when democracy index perception was failing, it did encouraged again the country with some degree of incentives (visa liberalization) but still it failed to achieve the EU requests. When EU used more pressure on conditionality by freezing financial incentives and warning for freezing visa liberalization the country still did not achieved the compliance that EU was requesting.

Differently in the case of Kosovo I argue that EU changed its conditionality approach. It used the approach "learn by doing": reaching a certain degree of compliance than rewarding with different incentives. This approach can have some features with the "standarts before status" used by UN in 2003. In overall EU conditionality used to be more reliable in the case of Kosovo than in the case of $\mathrm{BiH}$ in terms of achieving a more balanced degree of democratization.

\section{Conclusion}

This paper aimed to analyze how the EU enlargement process, through conditionality has influenced the democratization in the post-conflict countries of Western Balkans, in a comparative study of BiH and Kosovo. In doing so, I assumed that although EU strength coercive pressure through Conditionality regarding the enforcement of Rule of Law and enhancement of civil liberties, democratization in post-conflict countries of SEE, stagnate.

After comparing the two case studies I argue that this argumentation need to be reformulated because of the findings that I achieved through the measurement of each case of study. I used primary data from Commission reports over the years and analyzed how the rule of law and civil liberties were preserved, furthered or absent to assess the democratization. From this comparison I found that in the case of $\mathrm{BiH}$ the conditionality used influence on some degree to enforcement of the rule of law and enhancement of civil liberties in the first phase (2005-2008) and there was a balance between requests and incentives. But when the country democracy index perception was failing, the EU still encouraged with incentives (visa liberalization) but although the country failed to achieve EU requests. Insofar, when EU used more coercive pressure on conditionality by freezing financial incentives and warning for freezing visa liberalization the country still did not achieve the degree of compliance with EU. Differently in the case of Kosovo, I argue that EU changed its conditionality approach. It used the approach "learn by doing": reaching a certain degree of compliance than rewarding with different incentives. This was useful prior to the feasibility study in 2012 and also after the country achieved the start of the SAA process.

In overall EU conditionality used to be more reliable in the case of Kosovo than in the case of BiH in terms of achieving a more balanced degree of democratization. This argumentation is in support of the assumption that I worked in the beginning of this paper, so it can be reformulated in this way: The EU strength its coercive pressure after assessing the non-compliance of the country $(\mathrm{BiH})$ with the Conditionality, that is why democratization stagnate. But it "learns by doing" when it comes for Kosovo, using a balanced coercive pressure and after that rewarding with incentives.

\section{References}

European Commission (2005) Bosnia and Herzegovina Progress Report in "Enlargement Strategy and Main Challenges" 2005-2006 p.176

Chandler D. 2003 "The European Union and Governance in the Balkans: A Unequal Partnership in European Balkan Observer vol. 1 No.2 Published by the Belgrade Centre for European Integration and The Vienna Institute for International Economic Studies pp.1-26 Avaiable: http://www.davidchandler.org/wp-content/uploads/2014/10/EBO.pdf (Accessed 20.01.2015)

European Commission (2008) Bosnia and Herzegovina Progress Report" in "Enlargement Strategy and Main Challenges" 2008-2009 p.1-64

European Commission (2009) Bosnia and Herzegovina Progress Report" in "Enlargement Strategy and Main Challenges" 2009-20010 p.1-67

European Commission (2010) Bosnia and Herzegovina Progress Report" in "Enlargement Strategy and Main Challenges" 2010-2011 p.1-65

European Commission (2012) Bosnia and Herzegovina Progress Report" in "Enlargement Strategy and Main Challenges" 2012-2013 p.1-60

European Commission (2014) Bosnia and Herzegovina Progress Report" in "Enlargement Strategy and Main Challenges" 2014-2015 p.1-68

European Commission (2008) Kosovo (UNDER UNSCR 1244/99) Progress Report" in "Enlargement Strategy and Main Challenges" 2008-2009 p.1-59

European Commission (2009) Communication from the Commission to the European Parliament and the Council Kosovo (Under UNSCR 1244/99) Fulfilling its European Perspective p.1-15 
European Commission (2010) Kosovo (UNDER UNSCR 1244/99) Progress Report" in "Enlargement Strategy and Main Challenges" 2010-2011 p.1-61

European Commission (2011) Kosovo (UNDER UNSCR 1244/99) Progress Report" in "Enlargement Strategy and Main Challenges" 2011-2012 p.1-64

European Commission (2012) Communication from the Commission to the European Parliament and the Council on a Feasibility Study for a Stabilisation and Association Agreement between the European Union and Kosovo (Under UNSCR 1244/99) p.1-14

European Commission (2013) Kosovo (UNDER UNSCR 1244/99) Progress Report" in "Enlargement Strategy and Main Challenges" 2013-2014 p.1-56

European Commission (2014) Kosovo (UNDER UNSCR 1244/99) Progress Report" in "Enlargement Strategy and Main Challenges" 2014-2015 p.1-64

Schimmelfennig, F. and Sedelmeier, U. 2004 "Governance by conditionality: EU rule transfer to the candidate countries of Central and Eastern Europe" in Journal of European Public Policy 11:4 August 2004: 669-687 Avaiable: http://www.mzes.unimannheim. de/projekte/typo3/site/fileadmin/research\%20groups/1/teamBreader/Schimmelfennig\%20\%26\%20Sedelmeier_Governance\%20by\%20conditionality.pdf (Accessed 25.01.2015)

Sedelmeier, U. 2011 "Europeanisation in new member änd candidate states" in Living Reviews in European Governance, Vol. 6, (2011), No.1 pp. 1-52 Avaiable: http://europeangovernance.livingreviews.org/Articles/lreg-2011-1/download//reg-2011-1Color.pdf (Accessed 28.01.2015)

The Economist Democracy Index 2007 "The World in 2007: The Economist Intelligence Unit's index of democracy" ed. Laza Kekic. Avaiable: http://www.economist.com/media/pdf/DEMOCRACY_INDEX_2007_v3.pdf (Accessed 30.01.2015)

The Economist Democracy Index 2010 "The World in 2010: The Economist Intelligence Unit's index of democracy" ed. Laza Kekic. Avaiable: https://graphics.eiu.com/PDF/Democracy_Index_2010_web.pdf (Accessed 27.01.2015)

Tocci, N. The EU and Conflict Resolution: Promoting Peace in the Backyard, London: Roudge, 2007

UN Security Council Report: "Standards for Kosovo", presented in Prishtina 10 December 2003 http://www.securitycouncilreport. org/att/cf/\%7B65BFCF9B-6D27-4E9C-8CD3-CF6E4FF96FF9\%7D/Kos\%20Standards.pdf (Accessed 26.01.2015)

Wexel, Ch. and Aleksanderin, A.C. "Measuring Effective Democracy: The Human Empowerment Approach" in World Value Reseach vol.1 No.1 2008, pp.1-34 Avaiable: http://www.hse.ru/pubs/lib/data/access/ram/ticket/38/142220069500edf4927946165 62 e482 e595b75f084/WVR_01_01_Welzel_and_Alexander.pdf (Accessed 19.01.2015) 